\title{
Putting the Cart Before the Horse? Traders' Compliance with Kenya's Ban on Plastic Carrier Bags
}

\author{
${ }^{1}$ Elmah Odhiambo Geoffrey, ${ }^{1}$ Jane Mutheu Mutune, \\ ${ }^{1}$ Wangari Maathai Institute for Peace and Environmental Studies - University of Nairobi
}

\begin{abstract}
Plastic bags are non-biodegradable materials and consequently harmful to the environment. In spite of that, plastic is light and easy to make hence the increased production across the globe. This study was conducted in the aftermaths of Kenya's ban on plastic bags with the intention of analyzing how traders have complied with the ban. Compliance levels were reported to be lower in Kibera (30\%) compared to Karen (60\%). The banned plastic carrier bags were still in circulation and manufacturers blamed poor enforcement from the government and porous borders. Purportedly, traders were not given time to prepare and comply neither were they adequately consulted. The low compliance levels were attributed to limited public participation of the traders hence the need to adopt a circular economy model where every item is of value and consumers are able to reduce, recycle, reuse and relevant government agencies able to provide ecofriendly and affordable alternatives.
\end{abstract}

Keywords:- Plastics; Ban; Compliance; Circular Economy; Enforcement.

\section{INTRODUCTION}

Plastic bags have become a global menace due the growing evidence of their impact not only to human life but also aquatic life and the aesthetic value of the environment, between $60 \%$ and $80 \%$ of litter in oceans is plastic and 275 metric tons of waste generated in 192 coastal countries is made of plastic (Zamparo et al., 2018) depicting how dangerous plastics are. Plastics reduce aesthetic value and cleanliness of the physical environment.

The ban on plastic bags in Kenya has a history of previous failed attempts that were blamed on lack of political will, inadequate preparedness and lack of alternatives (Guardian, 2018). The negative impacts the bags pose not only to the environment but to both animals and human beings has been informing the bans and hence the Ministry of Environment and Forestry decided to attempt the ban one more time.

Plastic bags constructed with and without gussets and used for primary and domestic packaging were the targets of the ban imposed through the gazette notice No. 2356, the bags, apart from clogging drainage systems and pose ugly scenes on the environment, also act as breeding grounds for bacteria causing lifestyle diseases. Prior to the ban on plastic carrier bags in Kenya, about 100 million plastic bags were used each year in supermarkets alone, impacting the environment, human health and wildlife especially in areas where waste management systems are inadequate. In Western part of the country, veterinary doctors claimed that in their lifetime cows ingest an average of $2.5 \mathrm{kgs}$ of plastic bags, among other plastics (UNEP, 2017).

\section{LITERATURE}

The globe is already unable to cope with the amount of plastic waste it generates which has been on a steady increase (figure 1) according to Geyer et al., 2017. In the year 2015 alone, plastic packaging wastes accounted for $47 \%$ of the plastic wastes generated globally (300 million tons of plastic waste was generated), with half of the same appearing to have originated from Asia (Geyer et al., 2011). Plastics have caused the deaths of most livestock including aquatic animals, butchers who slaughter livestock report losses attributed to reduced weight since a lot of plastic left carelessly on the fields are ingested by livestock as others are driven by run off into the water bodies where they negatively affect the aquatic ecosystem.

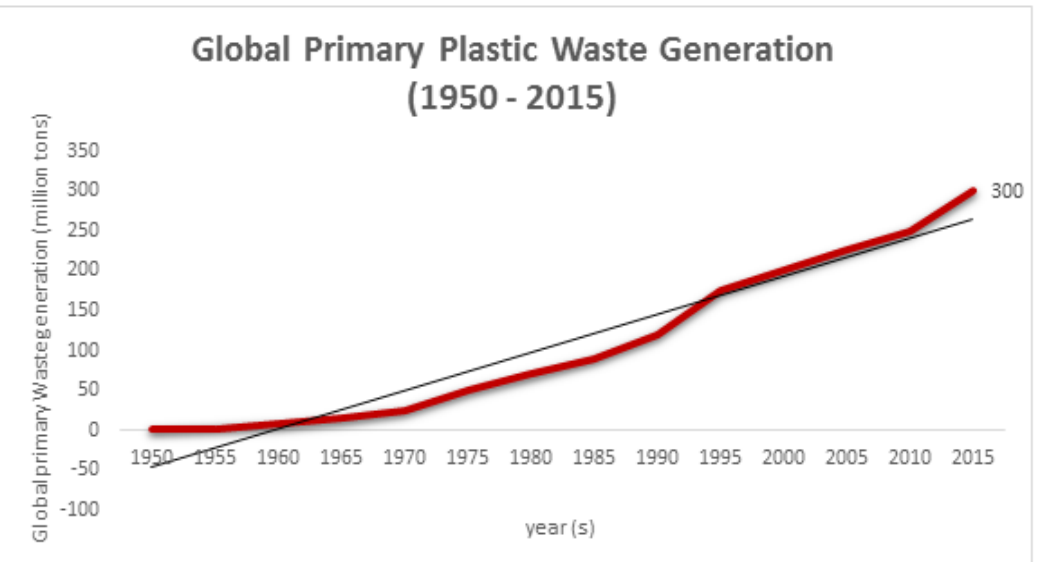

Fig 1:- Global Primary Plastic Waste Generation (1950-2015); Adapted from Geyer, Jambeck and Law, 2017 
The proliferation of plastic production globally accelerates climate change, according to the Centre for International Environmental Law (CIEL) plastics contribute to greenhouse gas emissions at every stage of their lifecycle; from production to when it is managed as wastes and the annual $\mathrm{CO}_{2}$ emissions from plastics could grow to more than 2.75 billion tons by 2050 if no urgent action is taken to halt it (Lisa et al., 2019). Improper solid waste management is one of Nairobi's most visible environmental obstacles; the stench that welcomes one into the city as a result of pollution caused by wastes on the roadside is unbearable (Odhiambo, n.d.), and with the over 2 thousand tons of wastes generated daily, the county government has acknowledged it can't manage ("How Nairobi can fix its serious waste problem," n.d.). More than a year and counting since the ban took effect, the banned plastic carrier bags are still in circulation among and between traders and consumers, and the manufacturing body cited loss of jobs and lack of stakeholder engagements that led them to seek the quash of the ban in court (Olulshula, 2018) and unavailability of proper alternatives (Ocharo, 2018) coupled by minimal preparedness with no efforts to revive the sisal industry that could provide ecofriendly alternatives("Traders and public unprepared for plastic ban - Daily Nation," n.d.).

A key indicator in governance effectiveness is how best regulatory systems are able to achieve their various policy needs (Wilthagen, 1997)). The response towards a given piece of legislation determines how effective its compliance will be. In Taiwan, a ban on plastics had to be reversed three years after it took effect due public and stakeholder outcry (Swanston and Jennifer, 2009), South Africa too had to settle for levies as a result of negative response to an intended ban from the key stakeholders. The understanding of whether individuals are sticking to their culture/habit or deviating from it to another could be the best indicator of compliance (Gilboy, 1998), the analysis of how traders responded to Kenya's ban on plastic carrier bags could therefore inform formulation and implementation of future policies.

\section{Theoretical Underpinning}

This research study was guided by Herbert A. Simon's (Simon, 1996) theory of Bounded Rationality. The Bounded Rationality theory argued that when people make decisions, the mind is bound by cognitive limits and restricts itself in making decisions (Deshpande, 2010) further that, rationality is limited by amenability of the decision problem, the intellectual limitations of the brain and the available time (Reinhard et al., 2002) hence the need to know what drove traders' response towards the ban on plastic carrier bags. The author hihglihgts elements that informs decision making; alternatives to the decisions, for example what are the alternatives to the ban on plastic bags, satisficing with learning and adaptation through environmental feedbacks (Wall, 2002). Another element is on inspiration to decision, what inspires individuals to make decisions, and this is in line with the objective that aims at finding out the constraints and opportunities associated with the ban among traders. The aspirations and goals of a decision maker normally is to adjust in response to the consequence of the decision to be made (Wall, 2002).

\section{MATERIALS AND METHODS}

This study was conducted in Nairobi County; Karen and Kibera estates in Kibra Division due to their close proximity and distinct social class with the aim of doing a comparative analysis on how the selected traders responded to the ban on plastic carrier bags. Karen is a suburb lying south of Nairobi's Central Business District majorly inhabited by relatively medium to high income earners with a population estimated to be nearing at least 30,000 people (KNBS, 2017). Major businesses taking place are wholesale and retail with small scale traders engaging in roadside businesses like food vending, retail shops, groceries, butchery among others. Most of these traders relied on plastic bags for packaging the traded products.

Kibera on the other hand is the largest informal settlement in Kenya and perhaps also the largest in Africa inhabited by low income earners; earning less than 1 dollar per a with unemployment rates being quite high (IMC, 2013). Most traders engage in food vending, in addition, there are numerous traders in retail shops, groceries and others are running butcheries and food vending (AI, 2018). Kibera's population across eleven villages is projected to be nearing at least 250,000 (KNBS, 2017) with the traders too being homogenous.

\section{RESEARCH DESIGN}

The study was a cross-sectional study, employing both qualitative and quantitative data collection methods. It involved initial reconnaissance study to determine the number of traders (the selected categories) existing in the two areas of study. The key traders were the butchers, grocers, vendors and retails shops operators since they were the most affected with the ban on plastic carrier bags. During the reconnaissance study it was established no official list of traders was in place thus the number of traders in both Kibera and Karen was not known. Owing to the homogeneity of the traders in the eleven villages in Kibera, one (Makina) village was used as a representative of the eleven villages.

\section{$>$ Sample Size Determination}

Based on the reconnaissance study, the population of the traders in Kibera and Karen unknown. Therefore, the researcher resorted to using Cochran's formula, when study population is unknown, to determine the sample size i.e.

$$
\mathrm{n}=Z^{2} p q / d^{2}
$$

Where;

$\mathbf{Z}$ is the standard normal deviation at $95 \%$ confidence level $=1.96$

$\mathbf{P}$ is the percentage picking a choice or response $=50 \%$ (0.5) - (Proportion in population based on pilot study)

d is the Standard error $=\mathbf{\pm 0 . 1}(10 \%)$, percentage at which the actual population is estimated at.

$\mathbf{q}$ is (1- $\mathbf{P})$ 
Using the above formula, the following was arrived at as the sample size for the study.

$\mathbf{n}=1.96^{2} \times 0.5 \times 0.5 / 0.1^{2}=$ Sample Size $(n)=96.04$. An additional attrition of $10 \%$ gives the used sample size as 106. This size was divided in the ration of $1: 3$ between the two areas based on the findings from the reconnaissance study which revealed that for every three traders in Makina Kibera, there is one such trader in Karen.

\section{Sampling Procedure}

The study used more than one method in sampling the respondents due to their complex arrangements. In Karen, the researcher employed a purposive sampling method to gather the needed data from the four categories of traders since the distribution of the targeted respondents was sparse except for Karen and Hardy Markets where a systematic random sampling was employed in collecting data to achieve the desired representation and avoid bias.

In Makina (Kibera), the sample distribution was dense and in order to achieve the desired representation, the researcher employed a systematic random sampling all through where; traders were picked one after every three along the transects defined by major roads; for the grocers, vendors and retailers. However, for the butchers, sampling was done purposively due to their spread along the transect.

\section{Data Analysis}

Data obtained was managed using the Statistical Package for Social Sciences (SPSS) and Microsoft Excel 2016. Analysis was done using means, frequencies and percentages. Additionally, a t-test was conducted to determine how independent variables; location and gender influenced how traders responded to the ban on plastic carrier bags.

\section{RESULTS AND DISCUSSIONS}

\section{$>$ Demographic Characteristics}

A total of 106 (one hundred and six) respondents interviewed came from Kibera and Karen estates which formed the study areas. The youngest respondents being 19 years and the oldest being 62 years of age; of the respondents interviewed $44 \%$ and $56 \%$ were males and females respectively, subsequently the distribution of the traders being even with majority being grocers at $41 \%$. Most of the respondents interviewed were the owners of the business they were doing with $67 \%$ owning the business and $33 \%$ were either employed or family members; son/daughter or relatives. Additionally, majority of the traders had been in the business for at least two years (47\%) making them useful for the study since the ban took effect one year before the study was conducted.

\section{Compliance/Response towards the ban on plastic carrier bags}

The response of stakeholders towards a given piece of legislation determines how effective the legislation will be complied with. About 57 and 30 percent of traders from Kibera and Karen respectively reported that the ban was not necessary. While $44 \%$ of the respondents from Karen opined that the ban on plastic bag was both necessary and not necessary explaining that the environment had become cleaner despite huge business losses as a result of limited packaging alternatives.

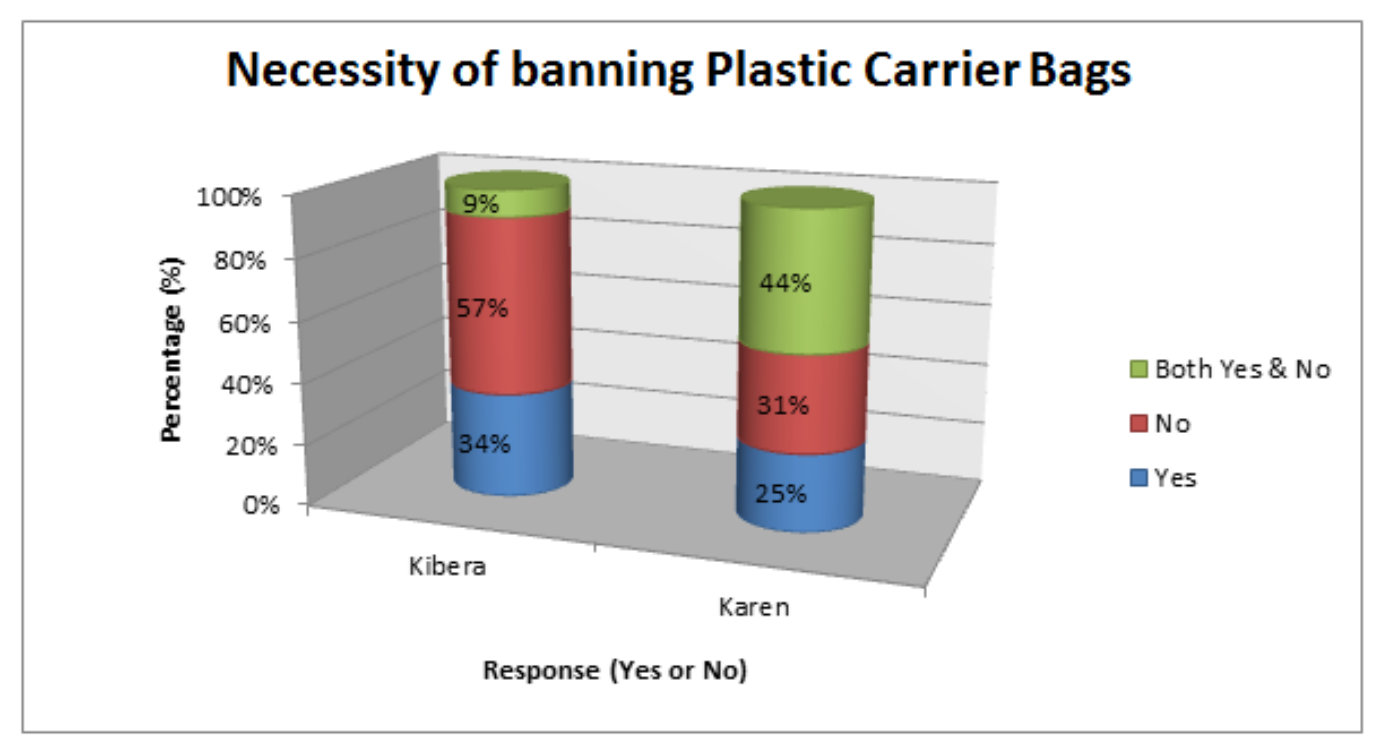

Fig 2:- Traders' response on whether it was necessary to ban the plastic carrier bags

Traders reported difficulty in doing business without the banned plastics bags because the reusable were deemed expensive and hence increased cost of business. About $80 \%$ of Kibera traders report that the physical environment remained dirty and littered despite the ban being intended to make surrounding cleaner. More than $60 \%$ of traders interviewed laments that there were no alternatives provided to them. The lack of alternatives packaging to the banned plastic bags has proven to be a threat to nations that have banned plastic bags in the quest to achieve full compliance. Nations that have indicated having little or no reports on compliance cite lack of enforcement and clear alternatives as their biggest challenge (UNEP, 2018). 
This study established that $70 \%$ of the respondents were not consulted and informed before the ban took effect. Whereas the $30 \%$ of respondents who were consulted reported having heard the decision to effect the ban on plastics through television and radio. Despite the importance of the ban to the traders' businesses there was no public forum in which they were involved to give their views on the plastic ban. About $50 \%$ of the traders, reported that they were not aware what kind of plastics had been banned thus complicating compliance among traders. Also a few key informants informed the study that traders were not given adequate time and neither were they extensively involved in the decision making before the ban was effected; a situation that could best be described as putting the cart before the horse.

To cope with the ban on plastic bags, some traders switched businesses while others looked for ways to access the banned plastics through porous borders from neighboring countries. A trader from Kibera laments on how they have to access the banned bags from Uganda while not able to access the right alternatives from Kenya. A vendor in Kibera as illustrated in the figures 3 and 4 below, points out that since she doesn't want to lose customers, she ensures the customer is satisfied by serving those without packaging materials using the banned plastic bags.

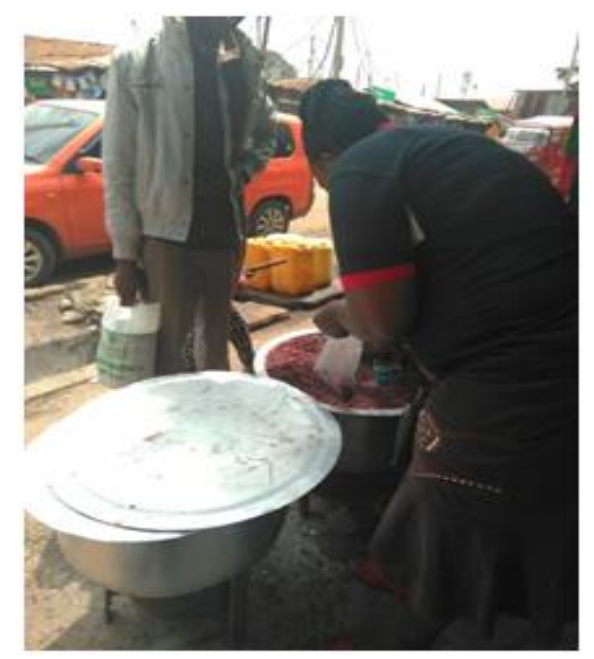

Fig 3:- A food vendor serving her customer with the banned plastic bag in Makina, Kibera. Source; Fieldwork

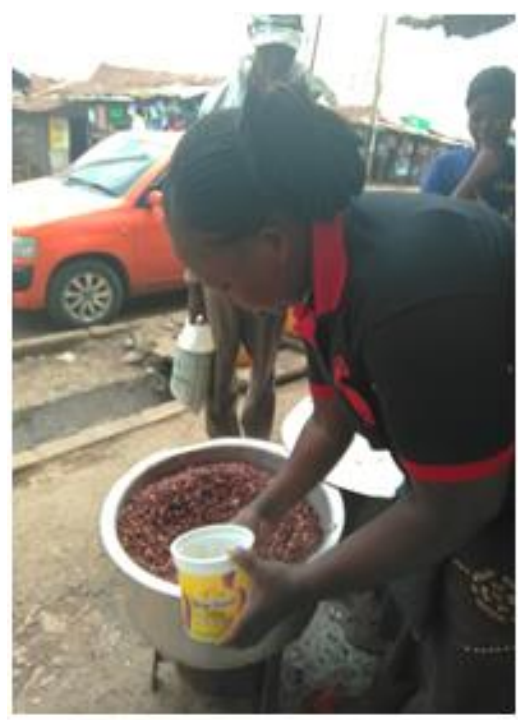

Fig 4:- A trader from Makina serving a customer using a reusable container; Source - fieldwork, 2018

According to Bii, 2018, plastic bag trade still thrives after the ban with manufactures blaming the government for poor enforcement (Koech, 2018). The study established that in the four categories of traders interviewed, at most $30 \%$ haven't complied and despite that, there are no records of those arrested, charged or imprisoned. In order therefore to achieve full compliance, a needs assessment is required to identify better and healthy alternatives for the traders. In table 1, there are traders who have stopped using the bags and have since switched the kinds of businesses they are doing, others too have not only stopped but gone ahead to introduce the reusable bags approved by the environmental agency. A NEMA officer laments that porous borders have made enforcement of the ban to be a challenge in the quest to end plastics in the country since there exist traders who can still access the plastics. 
ISSN No:-2456-2165

\begin{tabular}{|c|c|c|c|c|c|c|c|c|c|c|c|c|}
\hline \multirow[t]{2}{*}{ Compliance } & \multicolumn{4}{|c|}{ Overall \% } & \multicolumn{4}{|c|}{ Karen \% } & \multicolumn{4}{|c|}{ Kibera \% } \\
\hline & $\begin{array}{c}\text { Butchers } \\
(n=15)\end{array}$ & $\begin{array}{l}\text { Vendors } \\
(n=21)\end{array}$ & $\begin{array}{c}\text { Grocers } \\
(n=43)\end{array}$ & $\begin{array}{c}\text { Retailers } \\
(n=27)\end{array}$ & $\begin{array}{c}\text { Butchers } \\
(n=4)\end{array}$ & $\begin{array}{c}\text { Vendors } \\
(n=8)\end{array}$ & $\begin{array}{c}\text { Grocers } \\
(n=17)\end{array}$ & $\begin{array}{c}\text { Retailers } \\
\quad(n=7)\end{array}$ & $\begin{array}{c}\text { Butchers } \\
(n=11)\end{array}$ & $\begin{array}{l}\text { Vendors } \\
(n=13)\end{array}$ & $\begin{array}{c}\text { Grocers } \\
(n=26)\end{array}$ & $\begin{array}{c}\text { Retailers } \\
(n=20)\end{array}$ \\
\hline $\begin{array}{l}\text { Stopped } \\
\text { using the } \\
\text { plastics }\end{array}$ & 67 & 38 & 70 & 56 & 75 & 25 & 82 & 57 & 73 & 46 & 62 & 55 \\
\hline $\begin{array}{l}\text { Haven't } \\
\text { complied }\end{array}$ & 33 & 48 & 19 & 22 & 25 & 38 & 12 & 29 & 27 & 54 & 23 & 36 \\
\hline $\begin{array}{l}\text { Introduced } \\
\text { reusable } \\
\text { bags/ } \\
\text { friendly } \\
\text { alternatives }\end{array}$ & 93 & 67 & 86 & 93 & 100 & 88 & 100 & 100 & 82 & 54 & 73 & 90 \\
\hline
\end{tabular}

Table 1:- The Compliance Levels among traders in the study areas

Compliance with the ban is determined by many factors that include but limited to enforcement levels, location, gender, awareness levels and attitude towards/reception of a given piece of legislation (Ravara et al., 2013). The study reveals that even more than a year after the ban, still there were those who were not aware of the ban arguing that it was not clear to them which bags were banned thus depicting the lack of awareness from the environment agency. In Ireland, a robust awareness on the plastic bags levy led to $90 \%$ drop in the consumption of the bags (Ferreira, 2008). It was established that location and gender have significance influence on how traders responded to the ban, $(p<0.05)$.

\section{Available Packaging Alternatives and their Health} Implications

The banned plastic bags were the commonly packaging bags by consumers and traders in Kenya. The alternative packaging bags were hoped to be eco-friendly, affordable, healthy (easy to clean) and accessible. This study established that there was limited eco-friendly, clean and accessible alternative packaging materials. Traders reported that since the plastic carrier bags ban took effect, it has been difficult to do business and the blame is put on the lack of suitable alternatives to the banned plastic bags; it's like putting the cart before the horse.
The available alternatives to the traders after the ban included old/used newspapers, papers, non-woven reusable bags, net bags, and plastic cans. The packaged foods included fruits (both whole and sliced), cooked food, meat, vegetables and household goods. This implies that the traders had limited alternatives on how to package goods to the consumers. Additionally, about $40 \%$ of the traders were not sure whether the aforementioned alternatives were healthy and hygienic for packaging even though $20 \%$ of the respondents were bold that the alternatives were not healthy and hygienic. Additionally, about $15 \%$ point out that the available alternatives are somehow healthy while only about $25 \%$ are certain that the available alternatives are healthy. Even after knowing the alternatives are not healthy, they still use them because they have no alternatives. These findings resonate those of UNEP (2017b) which found that the lack of affordable, healthy and eco-friendly alternatives to the plastic bags has since proven to be a threat in the quest to eliminate plastics.

About eleven out of the sampled fifteen butchers relied on newspapers as the alternatives to the banned plastics as shown in table 2 below. Studies suggest that used newspapers exposes consumers to chemicals that negatively affects human health (Klick et al., 2012), these statistics therefore presents a health risk to consumers and needs to be dealt with.

\begin{tabular}{|c|c|c|c|c|c|c|c|c|}
\hline \multirow{2}{*}{ Alternative } & \multicolumn{2}{|c|}{ Butchers } & \multicolumn{2}{|c|}{ Vendors } & \multicolumn{2}{c|}{ Grocers } & \multicolumn{2}{c|}{ Retailers } \\
\cline { 2 - 8 } & $\mathbf{n = 1 5}$ & $\mathbf{\%}$ & $\mathbf{n = 2 1}$ & $\mathbf{\%}$ & $\mathbf{n = 4 3}$ & $\mathbf{\%}$ & $\mathbf{n = 2 7}$ & $\mathbf{\%}$ \\
\hline Papers e.g. from books & 6 & 40 & 7 & 33 & 13 & 30 & 18 & 67 \\
\hline Used Newspapers & 11 & 73 & 7 & 33 & 24 & 56 & 20 & 74 \\
\hline Net Bags & 1 & 7 & 1 & 5 & 4 & 9 & 5 & 19 \\
\hline Reusable bags (non-woven) & 14 & 93 & 20 & 95 & 39 & 91 & 27 & 100 \\
\hline Customers own items & 6 & 40 & 4 & 19 & 23 & 53 & 9 & 33 \\
\hline Others e.g. cling film & 0 & 0 & 1 & 5 & 3 & 7 & 2 & 7 \\
\hline
\end{tabular}

Table 2:- Available alternatives to the banned plastic carrier bags

A study done in the University of Arizona and Linda University revealed that failure to wash the reusable bags provided as alternatives could pose greater health risks caused by Bacteria (Lyali, 2017). This may occur as a result of continuously using the bag without washing and additionally mixing the goods together in one bag, especially meat and other foodstuffs inter alia thus precariously exposing the consumers to health risks. The reusable bags are prone to contacting germs and additionally act as agents to transmitting contagious diseases if not well handled (Aradi, 2017).

Canada at one point had to warn her customers on the potential dangers of cross contamination (Klick et al., 2012). California banned plastic bags in 2007, but studies done after the ban indicate that mortality rate increased and 
there were also frequent emergency room visits to health centers by consumers who had illnesses attributed to the use of reusable bags (Klick et al., 2012). One of the available alternatives to butcher operators are papers and used newspapers/magazines, however, the respondents interviewed laments how unhealthy it is to use the papers because of the health risks that result from the inks used in printing and the chemicals that may come therein, this agrees with the findings from a study (Muncke, 2011 ) that established health risks resulting from using paper and paper products which exposes consumers to phthalates as well as other suspected endocrine disruptors including benzophenones as well as mineral oils.

\section{CONCLUSIONS AND RECOMMENDATIONS}

\section{Conclusions}

Kenya's ban on plastic carrier bags is one the greatest things that would ever happen to a developing nation with the desire to ensure environmental sustainability. Not only has it tamed the habits of consumers but also proven to be a step forward in ensuring that there is a clean and healthy environment as provided for by Article 42 of the Kenya's Constitution 2010. Whereas the ban on plastic bags was not necessary as reported by traders, Kenyans should embrace recycling, reuse and reduce model.

Majority of the traders were not involved in the processes leading to the ban hence the difficulty in compliance. Additionally, the available packaging alternatives were expensive thus increasing business operation costs.

There was a difference in compliance between Karen and Kibera traders $(60 \%$ and $30 \%$ respectively). Compliance to plastic ban had picked up slowly occasioned by limited sensitization of the public on the ban, therefore public involvement is an important perquisite for a successful implementation of the ban.

\section{Recommendations}

All levels of governance ought to take center stage in key decision making especially those which affect the citizens directly, there is need for the government to revitalize the industries that will not only offer healthy alternatives but also create jobs; the sisal and cotton industries among others. The Ministry of Environment and Natural Resources and other government ministries should endeavor to have a broad range of stakeholder engagement in decisions regarding the plastic ban and other directives so as to ensure reasonable compliance levels. Additionally, the public ought to be sensitized on the adoption of a more circular model of economy that will ensure sustainable production and consumption with the overall goal being environmental sustainability.

\section{$>$ Policy Implications and Practice}

The ability of government policies and legislative strategies to be predictable and consistent enough is pivotal in attracting and retaining investors (KAM, 2017). The results of this study prove the claims by KAM that the stakeholders were not adequately involved before the ban was effected which is against the principle of public engagement entrenched in the constitution of Kenya (CoK) 2010 under article 118 and acknowledged by Public Participation Bill 2016 published through a Gazette Supplement No. 176.

The ban on plastic is a good move towards keeping the environment clean and reducing the amount of waste that goes into the land-fills. The involvement of stakeholders is crucial for the success of the ban. The current research revealed that the stakeholders were not adequately involved before the ban was effected yet the principle of public engagement is entrenched in the constitution of Kenya (CoK) 2010 under article 118 and acknowledged by Public Participation Bill 2016. Moreover, environmental education to educate the citizens on the importance of the 3 Rs i.e. reduce, reuse and recycling of plastic bags and this ought to be picked up by the Ministry of Environment and Forestry in liaison with the Ministry of Education. Additionally, it's important to inculcate responsibility among the citizens; this is possible through initiating strategies like, 'Adopt a road, river and any other vital resources. This will not only be making individuals responsible but also build on the aspirations of the Article 42 of the Constitution of Kenya (CoK) 2010.

\section{FUTURE RESEARCH}

The study recommends that further studies need to be conducted on the chemical analysis of the alternatives to the banned plastic bags including the no-woven reusable bags. Additionally, there is need to understand how different categories of consumers/general public have been affected by the ban and their attitudes on the same.

\section{ACKNOWLEDGEMENT}

Our gratitude goes to the Almighty God for granting me strength towards this course, and to all respondents in Karen, Kibera including key informants and research assistants. Many thanks to Dr. George Abong' for supporting this course from the start.

\section{REFERENCES}

[1]. Agency, E. (2011). Life Cycle Assessment of Supermarket carrier bags. In Journal of Photochemistry and Photobiology B: Biology (Vol. 46). https://doi.org/10.1016/S1011-1344(98)00196-1

[2]. AHI: United States \&quot; Kibera: Africa's largest slum. (2005). Retrieved from http://www.affordablehousinginstitute.org/blogs/us/ 2005/07/kibera_africas.html

[3]. Akullian, A., Karp, C., Austin, K., \& Durbin, D. (2006). Plastic bag externalities and policy in Rhode Island. Brown Policy Review. Retrieved from http://plasticbaglaws.org/wordpress/wpcontent/uploads/2010/02/study_plastic-bagexternalities-in-RI-2006.pdf 
[4]. Anastasio, M., \& Nix, J. (2016). Plastic Bag Levy in Ireland. $9 . \quad$ Retrieved from https://ieep.eu/uploads/articles/attachments/7f91cb9 7-8cb7-49c3-9cf0-d34062a9192e/IE Plastic Bag Levy conference draft.pdf?v=63673818840

[5]. Anderson, M. (2011). Famous, Rich And In The Slums Review: Putting Reality Back Into TV. OnTheBox. Retrieved from http://www.onthebox.com/tv/tv-reviews/famousrich-and-in-the-slums-review-putting-reality-backinto-tv/

[6]. Archived copy. (n.d.). Retrieved from http://www.unhabitat.org/downloads/docs/4626_839 92_GC 21 Africa on the Move.pdf

[7]. Avallone, I. V., Giraldi, J. D. M. E., \& Oliveira, S. V. W. B. de. (2012). Conscious Consumption: a Study on Plastic Bags' Consumers in Brazil. International Journal of Psychological Studies, 4(1), 122-134. https://doi.org/10.5539/ijps.v4n1p122

[8]. Ayalon, H., \& Livneh, I. (n.d.). Author's personal copy Social Science Research Educational standardization and gender differences in mathematics achievement: A comparative study.

[9]. Ayalon, O., Goldrath, T., Rosenthal, G., \& Grossman, M. (2009). Reduction of plastic carrier bag use: An analysis of alternatives in Israel. Waste Management, 29(7), 2025-2032. https://doi.org/10.1016/j.wasman.2009.02.016

[10]. Baconguis, B. (2018). STEMMING THE PLASTIC FLOOD Increasing restrictions and prohibitions on Single-use Plastics (SUPS). Retrieved from http://www.theworldcounts.com/counters/waste_pol lution_facts/plastic_bags_used_per_year

[11]. Barros, G. (2010). Herbert A. Simon and the concept of rationality: boundaries and procedures. Brazilian Journal of Political Economy, 30(3), 455472. 31572010000300006

[12]. BBC News - Improving sanitation in Kibera. (2011). Retrieved from https://www.bbc.co.uk/news/worldafrica-15095009

[13]. Benton, L. (2018). maturity ratings and other approaches Today we will discuss : KPIs vs Metrics. $1-10$.

[14]. Bharadwaj, B. (2016a). Plastic Bag Ban in Nepal: Enforcement and Effectiveness. (August). https://doi.org/10.13140/RG.2.1.4304.1528

[15]. Bharadwaj, B. (2016b). Plastic Bag Ban in Nepal: Enforcement and Effectiveness. Working Papers. Retrieved from https://ideas.repec.org/p/ess/wpaper/id11548.html

[16]. Blottnitz, H., \& Ngau, P. (2010). Integrated Solid Waste Management Plan for the City of Nairobi. (February), 30. Retrieved from www.unep.or.jp/.../IS_6_4_Nairobi_ISWMpl..

[17]. Bourguignon, D., EPRS, \& Bourguignon, D. (2015). Briefing Understanding waste management Policy challenges and opportunities. EPRS | European Parliamentary Research Service, (June). Retrieved from

http://www.europarl.europa.eu/RegData/etudes/BRI
E/2015/559493/EPRS_BRI\%282015\%29559493_E N.pdf

[18]. Breaking bag habits | Environment. (n.d.). Retrieved July $1, \quad 2019, \quad$ from https://ec.europa.eu/environment/efe/themes/waste/b reaking-bag-habits_en

[19]. Business as usual in counties as traders defy plastic bags ban - Daily Nation. (n.d.). Retrieved July 1, 2019, from https://www.nation.co.ke/news/Tradersdefy-plastic-bags-ban/1056-431322413oaoxsz/index.html

[20]. Challenges Of Waste Management And Disposal In Nairobi County: A Case Study Of Muthurwa Residence And Trading Centre In Muthurwa Location . (n.d.).

[21]. Chitechi, E. (2018). Live Green, Kenya Climate Innovation. (03), 9. Retrieved from www.kenyacic.org

[22]. CLARIFICATION OF PLASTIC BAN This is clarification to inquiries on the packaging plastic materials used by industries and other wrappings. According to the gazette notice No. 2334 of 14 . (2017). (2334), 2334.

[23]. Clayton, A., \& Savage, D. C. (1974). Government and labour in Kenya, 1895-1963. Cass.

[24]. Cleanup, C. (2017). Together Ocean.

[25]. Criticos bets on plastics ban to grow Taita Taveta sisal estate - Business Daily. (n.d.). Retrieved July 1, 2019 , from https://www.businessdailyafrica.com/news/counties/ Criticos-bets-on-plastics-ban-to-grow-Taita-Tavetasisal-estate/4003142-4367358-1yd6o2z/index.html

[26]. DEHP. (2017). Implementing a lightweight plastic shopping bag ban in Queensland Discussion paper Message from the Minister.

[27]. Dikgang, J., Leiman, A., \& Visser, M. (2012). ANALYSIS OF THE PLASTIC-BAG LEVY IN SOUTH AFRICA Regulations Governing Plastic Bags in South Africa. Resources, Conservation and Recycling, volume 66(18), 55-65. Retrieved from https://0-doi-

org.oasis.unisa.ac.za/10.1016/j.resconrec.2012.06.00 9

[28]. Earth Policy Institute. (2019). Plastic Bags Facts Sheet. (October 2014), 9290. Retrieved from http://www.earthpolicy.org/images/uploads/press_room/Plastic_Bags .pdf

[29]. Ecstasy as Kibera slum residents finally reach "promised land" after years of waiting. (2009). Retrieved from http://www.eastandard.net/InsidePage.php?id=1144 $024186 \&$ cid $=4$

[30]. Environment, N., Authority, M., National, T. H. E., Waste, S., \& Strategy, M. (2015). NEMA 2014 ii.

[31]. Equinox Center. (2013). Plastic Bag Bans: Analysis of Economic and Environmental Impacts. Equinox Center, (October), 1-36. Retrieved from https://energycenter.org/sites/default/files/PlasticBag-Ban-Web-Version-10-22-13-CK.pdf 
[32]. Erulkar, J. K. M. A. S. (n.d.). Adolescence in the Kibera Slums of Nairobi Kenya. Retrieved from http://www.popcouncil.org/pdfs/AdolKiberaSlums.p df

[33]. Facts and figures. (n.d.). Retrieved from http://www.kibera.org.uk/Facts.html

[34]. Farinelli, F., Bottini, M., Akkoyunlu, S., \& Aerni, P. (2011). Green entrepreneurship: the missing link towards a greener economy. Atdf Journal, 8(3/4), 42-48. Retrieved from http://www20.iadb.org/intal/catalogo/PE/2013/1081 6.pdf

[35]. Ferreira, F. H. G., Molinas Vega, J. R., Paes de Barros, R., \& Saavedra Chanduvi, J. (2008). Measuring Inequality of Opportunities in Latin America and the Caribbean. https://doi.org/10.1596/978-0-8213-7745-1

[36]. Forsner, T., Wistedt, A. A., Brommels, M., \& Forsell, Y. (2008). An approach to measure compliance to clinical guidelines in psychiatric care. BMC Psychiatry, $8(1), \quad 64$. https://doi.org/10.1186/1471-244X-8-64

[37]. Four arrested over possession of banned plastic bags - Citizentv.co.ke. (n.d.). Retrieved July 1, 2019, from https://citizentv.co.ke/news/four-arrested-overpossession-of-banned-plastic-bags-175385/

[38]. GESAMP. (2015). Sources, fate and effects of MP in the marine environment. 98. Retrieved from www.imo.org

[39]. GESAMP Joint Group of Experts on the Scientific Aspects of Marine Environmental Protection. (2016). Sources, fate and effects of microplastics in the marine environment: part 2 of a global assessment. (IMO, FAO/UNESCOIOC/UNIDO/WMO/IAEA/UN/UNEP/UNDP). In: Kershaw, P.J. (Ed.), Rep. Stud. GESAMP No. 90 (96 pp). Reports and Studies GESAMP, No. 93, 96 P., 93.

[40]. Geyer, R., Jambeck, J. R., \& Law, K. L. (2017). Production, use, and fate of all plastics ever made. Science Advances, 3(7), e1700782. https://doi.org/10.1126/sciadv.1700782

[41]. Giacovelli, C., Zamparo, A., Wehrli, A., \& Alverson, K. (2018). Single-use Plastic: A Roadmap for Sustainability. In United Nation Environment Programme. https://doi.org/DOI: 10.1016/0145305X(89)90168-7

[42]. Gooden, S. T. (2010). Social equity in public administration. The Future of Public Administration around the World: The Minnowbrook Perspective, (January), 53-58.

[43]. Groupement d'intérêt scientifique pour l'étude de la mondialisation et du développement (France). (n.d.). Mondialisation : les mots et les choses.

[44]. Health and Safety in Contemporary Britain: Society, Legitimacy, and Change ... - Paul Almond, Mike Esbester - Google Books. (n.d.). Retrieved July 1, 2019, from https://books.google.co.ke/books?id=M_CBDwAA QBAJ\&pg=PA129\&lpg=PA129\&dq=Aalders,+M.+ $\% 2526+$ Wilthagen,+T.+(1997),+\%25E2\%2580\%25
9CMoving+beyond+command-and-

control:+Reflexivity+in+the+regulation+of+occupat ional+health+and+safety+and+the+environment $\% 2$ 5E2\%2580\%259D+19+Law+\%252

[45]. Hoegh-Guldberg, O., Cai, R., Poloczanska, E. S., Brewer, P. G., Sundby, S., Hilmi, K., ... Jung, S. (2015). The ocean. Climate Change 2014: Impacts, Adaptation and Vulnerability: Part B: Regional Aspects: Working Group II Contribution to the Fifth Assessment Report of the Intergovernmental Panel on Climate Change, (January), 1655-1734. https://doi.org/10.1017/CBO9781107415386.010

[46]. Huppé, G. A., Paas, L., Voora, V., \& Creech, H. (2012). Social and Environmental Enterprises in the Green Economy: Supporting sustainable development and poverty eradication on the ground. 20.

[47]. Ibrahim, M. I. M., \& Mohamed, N. A. E. M. (2016). Towards Sustainable Management of Solid Waste in Egypt. Procedia Environmental Sciences, 34, 336347. https://doi.org/10.1016/j.proenv.2016.04.030

[48]. In, C., \& Location, M. (2014). Challenges Of Waste Management And Disposal In Nairobi County: A Case Study Of Muthurwa Residence And Trading Centre In Muthurwa Location . Challenges of Waste Management And Disposal In Nairobi County: A Case Study Of Muthurwa Residence And Trading. 2-3.

[49]. IRIN In-Depth | KENYA: Kibera, The Forgotten City $\mid$ Kenya | Environment | Urban Risk. (2006). Retrieved from http://www.irinnews.org/Report.aspx?ReportId=624 09

[50]. Jindal, R., Harada, H., \& Shikura, S. (1998). Solid Waste Management in Some Asian Countries. Environmental Systems Review, 42/43.

[51]. Jones, H. (2009). Equity in Development: Why It Is Important and How To Impact It. Overseas Development Institute, (311), 1-27. Retrieved from https://www.odi.org/sites/odi.org.uk/files/odiassets/publications-opinion-files/4577.pdf

[52]. June, A. (2017). Plastic Bags Ban Hailed. (June).

[53]. KARA, K. A. of R. A. (2017). Review of the Nairobi City County Solid Waste Management Draft Regulations , 2017 Submitted to the Kenya Alliance of Residents Associations ( KARA ). The Institute for Social Accountability, (October), 1-6.

[54]. Karanja, M. (2010). Myth shattered: Kibera numbers fail to add up. Retrieved from http://www.nation.co.ke/News/Kibera numbers fail to add up/-/1056/1003404/-/13ga38xz/-/index.html

[55]. Kasozi, A., \& Harro, B. Von. (2010). Solid Waste Management in Nairobi: A Situation Analysis. (February), 1-59. Retrieved from http://www.ecopost.co.ke/assets/pdf/nairobi_solid_ waste.pdf

[56]. Kenya. (2006). Retrieved from https://20012009.state.gov/g/drl/rls/hrrpt/2005/61575.htm 
[57]. Kenya Association of Manufacturers \& 2 others $v$ Cabinet Secretary - Ministry of Environment and Natural Resources \& 3 others [2017] eKLR. (2017). 2017(32), 1-9.

[58]. Kenya begins huge slum clearance. (2009). Retrieved from http://news.bbc.co.uk/1/hi/world/africa/8258417.stm

[59]. Kenya moves 1,500 slum residents to new homes. (2009). Retrieved from https://www.google.com/hostednews/ap/article/ALe qM5i2mIs1YGVZOqru3LLXpzLNtLJDnQD9AOF4 $\mathrm{CO0}$

[60]. Kibera to Nairobi. (n.d.). Google Maps. Retrieved from

https://www.google.com/maps/dir/Kibera,+Nairobi, +Kenya/Nairobi,+Kenya/@ -

$1.3004784,36.7856979,14 \mathrm{z} /$ data $=! 3 \mathrm{~m} 1 ! 4 \mathrm{~b} 1 ! 4 \mathrm{~m} 14 ! 4$

$\mathrm{m} 13$ ! $1 \mathrm{~m} 5$ ! $1 \mathrm{~m} 1$ ! $1 \mathrm{~s} 0 \mathrm{x} 182 \mathrm{f} 107 \mathrm{~d} 3 \mathrm{ba} 89 \mathrm{c} 15: 0 x \mathrm{efcfe} 2 \mathrm{ec} 9$ $0115 \mathrm{ed} 2$ ! $2 \mathrm{~m} 2$ ! $1 \mathrm{~d} 36.7846436$ ! $2 \mathrm{~d}-$

1.3133048 ! $1 \mathrm{~m} 5$ ! $1 \mathrm{~m} 1$ ! $1 \mathrm{~s} 0 \times 182 \mathrm{f} 1172 \mathrm{~d} 84 \mathrm{~d} 49 \mathrm{a} 7: 0 \times \mathrm{xf} \mathrm{c}$ f0254b297924c!2m2!1d36.8219462!2d$1.2920659 ! 3 \mathrm{e} 0$

[61]. KIPPRA. (2017). Policy Monitor:Ban on Plastic Bags Finally Takes Effect in Kenya. Anthropology News, 44(6) https://doi.org/10.1111/an.2003.44.6.54

[62]. Leeuwen, A. van. (2012). Negative Health and Environmental Impacts of Reusable Shopping Bags. (December), 1-16.

[63]. Lowder, S. (1986). The geography of Third World cities. Totowa, N.J.: Barnes Noble Books.

[64]. Marsden Jacob Associates. (2016). Plastic Bags Ban Options -Cost Benefit Analysis. Victorian Department of Environment, Land, Water and Planning, 28.

[65]. Metrics, C. (2016). Compliance metrics.

[66]. Muigua, K. (n.d.). Reconceptualising the Right to Clean and Healthy Environment in Kenya Kariuki Muigua.

[67]. Muigua, K., \& Kariuki, F. (2015). Towards Environmental Justice in Kenya.

[68]. Nava, M. (2017). Fighting Ocean Plastic Pollution Bringing opportunities in the circular economy Chart 1. Global plastic and steel production (Million metric tons) Chart 2. Global plastic production by industrial sector in $2015(\%)$. Source: UN Environment, 3(7), 1-8. Retrieved from https://goo.gl/4TJTn3

[69]. Nema closes Burma market for violating plastics bags ban - Daily Nation. (n.d.). Retrieved July 1, 2019, from https://www.nation.co.ke/counties/nairobi/Nemashuts-Burma-market-plastic-bags-use/19541744316026-fvt4cyz/index.html

[70]. Nilsen, A. (2010). An Economic Evaluation of Plastic Bag Regulation_MasterThesis.

[71]. Nyawira, Mugo, A. (2016). Enterprises in Accessing East African Markets.

[72]. Odhiambo, E. (n.d.). Roadside Wastes Sources, Impacts and Mitigation Measures.

[73]. Paper, W. (2006). www.econstor.eu.
[74]. Parliament of Kenya. (2015). ffiH : CfIVHD. 74(74), $1-44$.

[75]. PLASTIC PRIMARY INDUSTRIAL PACKAGING CLEARANCE REGISTER. (n.d.).

[76]. Republic of Kenya. (2010). Laws of Kenya. National Council For Law Reporting, 24. Retrieved from www.kenyalaw.com

[77]. Reusable shopping bags are full of germs and could make you sick. (n.d.). Retrieved July 1, 2019, from https://www.news.com.au/lifestyle/health/healthproblems/turns-out-using-a-reusable-shopping-bagcould-be-making-you-sick/newsstory/e994b4ca811a0c9af4c9948c50b37a26

[78]. Rodriguez-Torres, D. (2010). Nairobi today: the paradox of a fragmented city. Mkuki na Nyota Publishers.

[79]. Rodriguez-Torres, D., Charton-Bigot, H., \& Institut français de recherche en Afrique. (2006). Nairobi contemporain: les paradoxes d'une ville fragmentée. Karthala.

[80]. Rose, G. L. (2011). Gaps in the Implementation of Environmental Law at the National, Regional and Global Level. (October), 1-30.

[81]. Saidan, M. N., Ansour, L. M., \& Saidan, H. (2017). Management of Plastic Bags Waste: an Assessment of Scenarios in Jordan. Journal of Chemical Technology and Metallurgy, 52, 148-154. Retrieved from http://dl.uctm.edu/journal/node/j2017-1/19_1593_Motasem_p_148-154.pdf

[82]. Sampford, K., \& Leader, T. (2010). Plastic Shopping Bags. In Parliamentary Research Officer (Vol. 3406). Retrieved from http://www.parliament.qld.gov.au/documents/explor e/ResearchPublications/ResearchBriefs/2010/RBR2 01028.pdf

[83]. Schnurr, R. E. J., Alboiu, V., Chaudhary, M., Corbett, R. A., Quanz, M. E., Sankar, K., ... Walker, T. R. (2018). CO CO.

[84]. Selten, R. (1999). What is Bounded Rationality? Dahlem Conference 1999, (May), 1-25.

[85]. Shimanyula, J. (2014). Biogas helping to clean up Nairobi slum. Deutsche Welle. Retrieved from http://www.dw.de/biogas-helping-to-clean-upnairobi-slum/a-18023280

[86]. Smedt, J. de. (2009). Kill Me Quick, A History of Nubian Gin in Kibera.

[87]. the guardian, kenyas ban on plastics - Google Search. (n.d.). Retrieved July 1, 2019, from https://www.google.com/search?client=firefox-b$\mathrm{d} \& \mathrm{q}=$ the + guardian $\% 2 \mathrm{C}+$ kenyas + ban $+\mathrm{on}+$ plastics

[88]. The strange allure of the slums. (2007). The Economist. Retrieved from http://www.economist.com/node/9070714

[89]. Theories, E. (2004). 3 . Existing Theories Considering Technology Adoption. Technology Acceptance in Mechatronics, 9-28. https://doi.org/10.1007/978-3-8349-8375-6_3

[90]. There's an opportunity in plastics ban - Daily Nation. (n.d.). Retrieved July 1, 2019, from https://mobile.nation.co.ke/blogs/1949942-3967330format-xhtml-3uxkchz/index.html 
[91]. Trang, P. T. T., Dong, H. Q., Toan, D. Q., Hanh, N. T. X., \& Thu, N. T. (2017). The Effects of Socioeconomic Factors on Household Solid Waste Generation and Composition: A Case Study in Thu Dau Mot, Vietnam. Energy Procedia, 107(September 2016), 253-258. https://doi.org/10.1016/j.egypro.2016.12.144

[92]. Tunapanda Institute. (n.d.). Social Tech Guide. Retrieved from https://www.socialtech.org.uk/projects/tunapandainstitute/

[93]. UNEP. (2018). Report on the Status of Styrofoam and Plastic Bag Bans in the Wider Caribbean Region. (July).

[94]. UNEP L.pdf. (n.d.).

[95]. Up, C. (2007). Clean Up Australia Plastic Bags World Report Countries or cities taking action on plastic bags : 1-14.

[96]. Upwardly mobile Africa: Boomtown slum. (2012). 59. $\quad$ Retrieved from https://www.economist.com/news/christmas/215685 92-day-economic-life-africas-biggest-shanty-townboomtown-slum

[97]. Uwadiegwu, B. O., \& Chukwu, K. E. (2013). Strategies for Effective Urban Solid Waste Management in Nigeria. European Scientific Journal, 9(8), 1857-7881.
[98]. Van Leeuwen, A. (2013). Bacterial and Viral Health Hazards Of Reusable Shopping Bags What Proponents of Bag Bans Will Never Tell You. (reusable shopping bag), 9. Retrieved from http://fighttheplasticbagban.com

[99]. Video: The women of Kibera in Kenya | Amnesty International. (2009). Retrieved from https://www.amnesty.org/en/news-andupdates/video-and-audio/video-women-kiberakenya-20090306

[100]. Walker, T. R., \& Xanthos, D. (2018). A call for Canada to move toward zero plastic waste by reducing and recycling single-use plastics. Resources, Conservation and Recycling, 133(February), 99-100. https://doi.org/10.1016/j.resconrec.2018.02.014

[101]. Yale, I., Law, I., \& Swanston, S. F. (1993). Legal Strategies for Achieving Environmental Equity Environmental Equity. 18(1).

[102]. Zhu, Q. (2011). An appraisal and analysis of the law of "Plastic-Bag Ban." Energy Procedia, 5, 25162521. https://doi.org/10.1016/j.egypro.2011.03.432

[103]. Zink, T., Geyer, R., \& Startz, R. (2018). Toward Estimating Displaced Primary Production from Recycling: A Case Study of U.S. Aluminum. Journal of Industrial Ecology, 22(2), 314-326.

\section{APPENDICES}

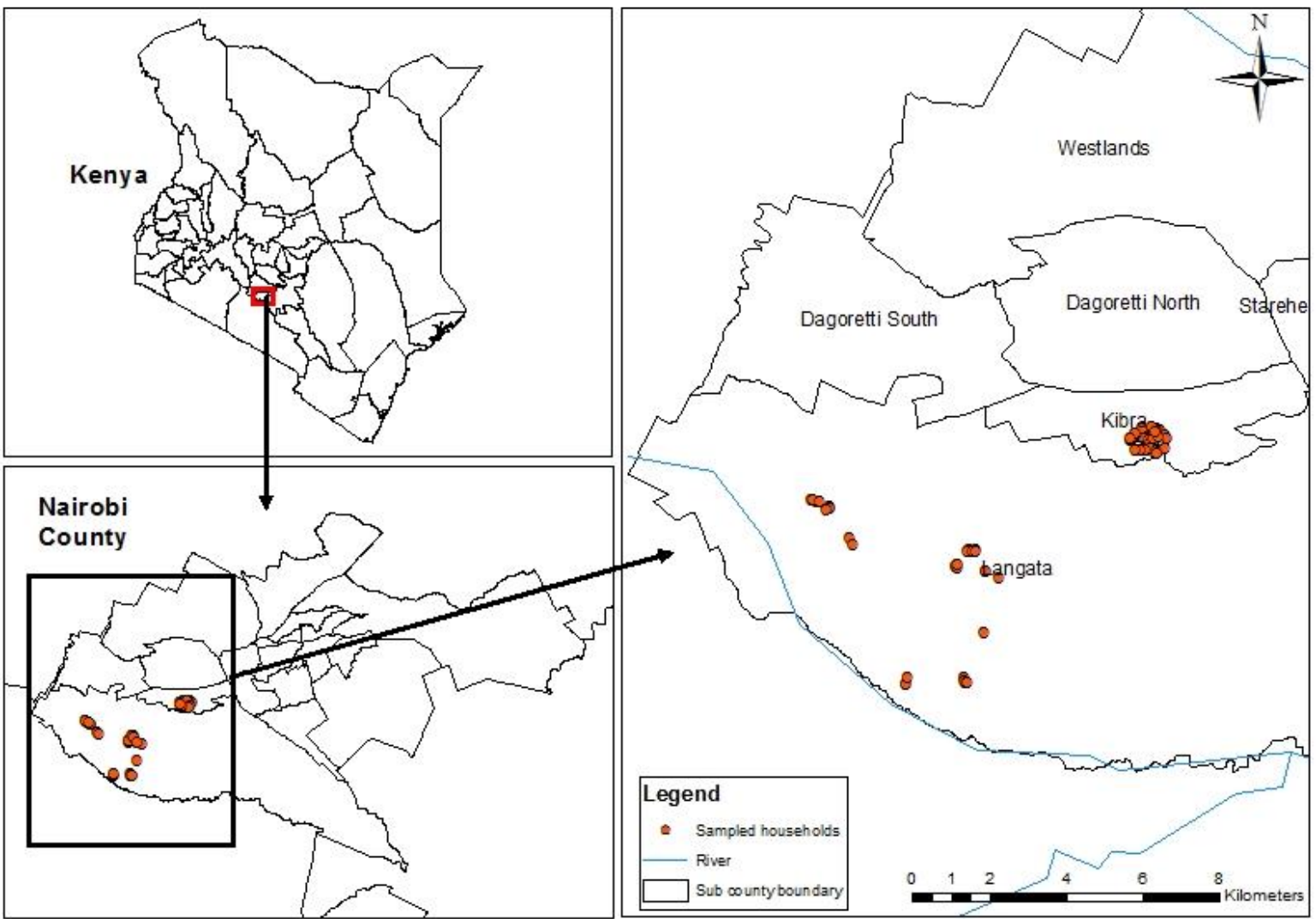

Fig 5:- Map of Study Area 
Appendix 2: Result from a t-test on independent variables against response to the ban

\begin{tabular}{|c|c|c|c|c|c|c|}
\hline Variable (s) & Mean & Std. Deviation & $\begin{array}{c}\text { Std. Error } \\
\text { Mean }\end{array}$ & $t$ & $d f$ & p-Value \\
\hline \multicolumn{7}{|c|}{ Response to the ban } \\
\hline Gender & -.34 & .84 & .08 & -4.17 & 105 & .000 \\
\hline Location & -.56 & .73 & .07 & -7.84 & 105 & .000 \\
\hline Level of education & -.04 & 1.02 & .10 & -.38 & 105 & .705 \\
\hline Age & 31.22 & 8.15 & .79 & 39.45 & 105 & .000 \\
\hline Age & -1.10 & 1.33 & .13 & -8.54 & 105 & .000 \\
\hline
\end{tabular}

Table 3:- T-test on independent variable against the response to the ban

\section{Appendix 3: List of Abbreviations}

AI : Amnesty International

CIEL : Centre for International Environmental Law

CoK : Constitution of Kenya, 2010

KAM : Kenya Association of Manufacturers

KNBS : Kenya National Bureau of Statistics

NEMA : National Environment Management Agency

SPSS : Statistical Package for Social Sciences

UNEP: United Nations Environment Program 